\title{
Identifikasi komponen dan Uji Potensi Anti Jamur Minyak Atsiri Serai Dapur (Cympobogon citratus) Terhadap Jamur Penghasil Aflatoksin
}

\section{Component identification and the Measurement of Antifungal Potential of Lemongrass oil against Aflatoxin Producing Fungi}

\section{Rini Yanti, Hermina Nurdiawati, Muhammad N. Cahyanto, Yudi Pranoto}

Departemen Teknologi Pangan dan Hasil Pertanian, Fakultas Teknologi Pertanian, Universitas Gadjah Mada, Jl. Flora no 1, Yogyakarta 55281, Indonesia

*Penulis korespondensi: Rini Yanti, e-mail: riniyanti@ugm.ac.id

Tanggal submisi: 13 Juli 2020; Tanggal penerimaan: 25 September 2020

\begin{abstract}
Aspergillus flavus and A. parasiticus are food spoilage fungi and produce aflatoxin that causes serious food safety problems. The antifungal agent is needed to control these fungi. This study aimed to determine the component of lemongrass essential oil and to test the oil's ability to inhibit the growth of A. flavus and A. parasiticus. Five variations in the concentration of lemongrass oil were tested separately on A. flavus and A. parasiticus and, fungal growth was observed for 7 days. The results of the identification of the essential oil components using GC-MS showed that lemongrass essential oil has the main components of citral (53.77\%) and z-citral (34.05\%). Lemongrass essential oil with various concentrations $(0.01 \% ; 0.02 \% ; 0.04 \%$ and $0.08 \%)$ showed the ability to inhibit the growth of A. flavus and A. parasiticus and the concentration of $0.08 \%$ indicated that lemongrass oil could inhibit the growth of both fungi for 100\% during 7 days of observation.
\end{abstract}

Keywords: antifungal, aflatoxin, citral, essential oil, lemongrass oil

\begin{abstract}
ABSTRAK
Aspergillus flavus dan A. parasiticus merupakan jamur yang banyak ditemukan mengkontaminasi pangan. Kedua jamur tersebut menghasilkan aflatoksin, yang berbahaya bagi kesehatan manusia, sehingga diperlukan anti-jamur untuk mengendalikan pertumbuhannya. Penelitian ini bertujuan untuk mengetahui komponen minyak atsri serai (Cymbopogon citratus) dan menguji kemampuan minyak tersebut sebagai penghambat pertumbuhan A. flavus dan A. parasiticus. Lima variasi konsentrasi minyak serai diujikan secara terpisah pada A. flavus dan A. parasiticus dan dilakukan pengamatan pertumbuhan jamur selama 7 hari. Hasil identifikasi komponen minyak atsiri menggunakan GC-MS menunjukkan bahwa minyak atsri serai memiliki komponen utama citral $(53,77 \%)$ dan z-citral $(34,05 \%)$. Minyak atsiri serai dengan berbagai konsentrasi $(0,01 \% ; 0,02 \% ; 0,04 \%$ dan $0,08 \%)$ menunjukkan kemampuan menghambat pertumbuhan A. flavus dan A. parasiticus dan konsentrasi $0,08 \%$ menunjukkan bahwa minyak serai mampu menghambat pertumbuhan kedua jamur sebesar $100 \%$ selama 7 hari pengamatan
\end{abstract}

Kata kunci: antijamur, aflatoksin, minyak atsiri, minyak serai, sitral

\section{PENDAHULUAN}

Aspergillus flavus dan Aspergillus paraciticus merupakan dua jenis jamur yang sering mengkontaminasi bahan pertanian, baik pangan maupun pakan (Davari et al., 2015). Di Indonesia, A. flavus dan A. parasiticus banyak ditemukan mengkontaminasi serealia dan kacang-kacangan (Sardjono et al., 1992). Kedua jamur tersebut tidak hanya mengkontaminasi pangan yang menyebab- 
kan penurunan kualitas produk tersebut, tetapi juga dapat menghasilkan mikotoksin seperti aflatoksin. Aflatoksin diketahui mempunyai potensi untuk menimbulkan potensi mutagenic, carcinogenic, teratogenic, hepatotoxic, dan immunosuppressive, dan juga menghambat beberapa sistem metabolik (Bluma dan Etcheverry, 2008).

Perlakuan yang biasa dilakukan untuk mengendalikan pertumbuhan jamur adalah pemberian fungisida sintetis, akan tetapi penggunaan fungisida sintetis mulai ditinggalkan karena trend pola hidup sehat dengan makanan alami sedang berkembang di masyarakat. Akhir dekade ini, perhatian masyarakat akan bahaya residu, polutan, karsinogen, fitotoksik yang ditimbulkan oleh penggunaan fungisida sintetis meningkat. Hal ini mendorong penemuan alternatif bahan alami sebagai fungisida yang aman untuk mengontrol kontaminasi jamur fitopatogen. Pertimbangan lain adalah kemampuannya diuraikan secara biologi (biodegradable), bisa diperbaharui (renewable), dan aman untuk kese-hatan manusia. Beberapa minyak atsiri telah diklasifikasikan sebagai Generally Recognized as Safe (GRAS) dan aktivitas anti jamur dan antibakteri pada berbagai mikroorganisme telah dilakukan pada penelitian sebelumnya (Tripathi et al., 2009).

Terdapat berbagai jenis tanaman di Indonesia yang dapat dimanfaatkan dalam bentuk minyak atsiri. Salah satu jenis tanaman yang dapat diambil minyak atsirinya adalah tanaman rempah. Dalam penelitian ini, minyak atsiri dari serai dievaluasi sifat anti-jamurnya terhadap A. flavus dan A. parasiticus. Pertimbangan pemilihan serai tersebut dimaksudkan sebagai antisipasi kemungkinan flavor yang ditimbulkan oleh penggunaan minyak atsiri masih bisa diterima oleh konsumen, karena serai merupakan bahan yang banyak digunakan untuk makanan dan minuman.

Tujuan penelitian adalah mendapatkan bahan alami yang dapat menghambat pertumbuhan $A$. flavus dan A. parasiticus dan dapat digunakan dalam pengawetan komoditas pertanian yang mudah terkontaminasi jamur tersebut. Tujuan khusus penelitian ini menentukan komponen penyusun minyak atsiri yang diperoleh dari metoda distilasi air dan uap dan mengevaluasi potensinya sebagai anti-jamur pada A. flavus dan A. parasiticus.

\section{METODA PENELITIAN}

\section{Bahan}

Bahan utama yang digunakan dalam penelitian ini adalah serai dapur (Cymbopogon citratus) yang diperoleh Pasar Beringharjo, Yogyakarta. Mikroorganisme yang digunakan dalam penelitian ini adalah biakan murni A. flavus FNCC 6133 dan A. parasiticus FNCC 6033 dari Laboratorium Mikrobiologi Pusat Studi Pangan Gizi UGM, Yogyakarta.

\section{Preparasi Minyak Atsiri}

Batang serai (Cymbopogon citratus) yang telah dikeringkan dan dipotong-potong sepanjang 1-2 cm, kemudian ditempatkan pada ketel alat distilasi. Ketel dan rangkaian alat distilasi merupakan peralatan rancangan dari bengkel alat Universitas Gadjah Mada. Minyak atsiri diperoleh dengan distilasi menggunakan metode uap dan air dengan rasio air distilasi dan bahan adalah $5: 1$ (v/b). Waktu distilasi adalah 4 jam, dimulai ketika distilat mulai menetes dengan suhu distilasi $96^{\circ} \mathrm{C}$. Hasil distilasi yang masih berupa campuran minyak dan air ditampung kemudian dipisahkan menggunakan corong pemisah. Minyak yang diperoleh dari pemisahan ditambah $\mathrm{Na}_{2} \mathrm{SO}_{4}$ anhidrat (Merck, Germany), sebanyak $1 \mathrm{~g}$ untuk setiap $10 \mathrm{~mL}$ minyak, untuk menangkap titik-titik air yang masih terikut, kemudian disaring menggunakan kertas Whatman 42 (GE Healthcare, UK). Minyak atsiri disimpan dalam botol gelap yang ditutup rapat dan disimpan pada suhu $4^{\circ} \mathrm{C}$ (Yanti, 2018). Hasil yang didapatkan dihitung rendemen dan dianalisa sifat fisik dan kimianya meliputi, bobot jenis (Guenther, 1987), indeks refraksi, kelarutan dalam alkohol (Guenther 1987), angka asam dan angka ester (Sudarmadji, 2003)

\section{Identifikasi Komponen Kimia Minyak Atsiri}

Identifikasi komponen kimia penyusun minyak atsiri serai dilakukan menggunakan Gas Chromatography- Mass Spectroscopy (GC-MS). Minyak atsiri dianalisis menggunakan GCMSQP2010S (Shimadzu, Japan) dilengkapi dengan kolom Rtx-5MS (panjang $30 \mathrm{~m}$, diameter dalam $0,25 \mathrm{~mm})$. Sebanyak $0,1 \mu \mathrm{L}$ minyak atsiri diinjeksikan dalam kolom dengan kondisi operasi temperatur injektor: $290^{\circ} \mathrm{C}$, suhu oven dari $70^{\circ} \mathrm{C}$ hingga $280^{\circ} \mathrm{C}\left(4^{\circ} \mathrm{C} /\right.$ menit $)$, gas pembawa He dengan kecepatan aliran $0,5 \mathrm{~mL} / \mathrm{menit}$ pada $290^{\circ} \mathrm{C}$, split ratio 193, dan tekanan $13,7 \mathrm{kPa}$ (Yanti et al., 2018).

\section{Preparasi Spora Jamur}

Strain mikrobia A. flavus dan A. parasiticus masing-masing ditanam pada media Potato 
Dextrose Agar (PDA) (Merck, Germany) miring kemudian diinkubasi pada suhu $30^{\circ} \mathrm{C}$ selama 7 hari. Spora dipanen dengan menambahkan $3 \mathrm{~mL}$ larutan $0,05 \%$ tween 80 steril. Permukaan agar miring digores perlahan-lahan hingga spora terlepas dan diperoleh stok spora dalam bentuk suspensi. Stok spora kemudian diencerkan menggunakan larutan $0,05 \%$ tween 80 hingga diperoleh konsentrasi spora $10^{7}$ spora $/ \mathrm{mL}$. Penghitungan konsentrasi spora dihitung menggunakan haemocitometer Neubauer (Assistent, Germany).

\section{Pengujian Aktivitas Penghambatan}

Pengujian aktivitas antijamur Aspergillus flavus dan Aspergillus parasiticus dilakukan dengan food poisoned technique (Perrucci et al., 1994) menggunakan media PDA. Minyak atsiri yang digunakan ditambahkan ke dalam medium bersuhu $50-55^{\circ} \mathrm{C}$ dan kemudian dituang pada petri dish berdiameter $10 \mathrm{~cm}$. Dilakukan variasi konsentrasi minyak atsiri serai $0 \% ; 0,01 \% ; 0,02 \% ; 0,04 \%$ dan $0,08 \%$. Penambahan minyak atsiri ke dalam media dilakukan dengan cara mencampurkan sejumlah minyak atsiri sesuai dengan konsentrasi yang diinginkan dengan penambahan $0,1 \%$ Tween 80 (Merck, Germany) sebagai emulsifier, kemudian campuran tersebut dituang kedalam media. Jamur kemudian diinokulasikan ketika media sudah padat sebanyak 3 titik per petri. Pengujian dilakukan sebanyak 2 ulangan. Kontrol dibuat dengan menumbuhkan jamur pada media dengan penambahan $0,1 \%$ Tween 80 namun tanpa penambahan minyak atsiri. Setelah itu diinkubasi pada suhu $30^{\circ} \mathrm{C}$. Pengamatan pertumbuhan jamur dilakukan setiap hari selama 7 hari dengan cara mengukur diameter koloni jamur. Persentase penghambatan pertumbuhan koloni jamur dapat dihitung dengan persamaan berikut (de Billerbeck et al., 2001).

Persentase Penghambatan $=\frac{D c-D o}{D c} \times 100 \%$

Keterangan: $D c=$ Diameter rata-rata koloni kontrol; $D o=$ Diameter rata-rata koloni perlakuan

\section{HASIL DAN PEMBAHASAN}

\section{Analisis Sifat Fisik dan Kimia Minyak Atsiri}

Rendemen dan sifat-sifat minyak atsiri serai disajikan pada Tabel 1. Rendemen minyak atsiri serai yang didapatkan setelah distilasi air dan uap dalam penelitian ini adalah sebesar $1,82 \%(\mathrm{db})$.
Sementara itu sifat fisik dan kimia dari minyak serai ini adalah sebagai berikut: bobot jenis minyak serai pada suhu $20^{\circ} \mathrm{C}$ adalah 0,89 , indeks refraksi minyak serai pada suhu $20^{\circ} \mathrm{C}$ berdasarkan hasil penelitan adalah 1,48, angka asam 11,04 mg KOH/g minyak dan larut dalam alkohol $95 \%$ (perbandingan 1:1).

Tabel 1. Sifat fisik dan kimia minyak serai

\begin{tabular}{lll}
\hline No & \multicolumn{1}{c}{ Jenis analisis } & \multicolumn{1}{c}{ Hasil } \\
\hline 1. & Kadar air & $51,42 \%$ \\
2. & Rendemen minyak & $1,82 \%$ \\
3. & Bobot jenis pada suhu $20^{\circ} \mathrm{C}$ & 0,89 \\
4. & Indeks refraksi pada suhu $20^{\circ} \mathrm{C}$ & 1,48 \\
5. & Angka asam & $11,04^{*}$ \\
6. & Kelarutan dalam alkohol & Larut, \\
& & $1: 1^{* *}$ \\
\hline
\end{tabular}

Keterangan: *) dalam mg KOH/g minyak; **) larut dalam alkohol 95\%, dengan perbandingan 1:1

Bobot jenis merupakan salah satu kriteria penting dalam menentukan mutu dan kemurnian minyak atsiri. Bobot jenis dipengaruhi oleh derajat ketidakjenuhan minyak dan berat molekul rata-rata senyawa penyusunnya. Nilai bobot jenis minyak atsiri berkisar antara $0,696-1,188$ pada suhu $15^{\circ} \mathrm{C}$, dan pada umumnya nilai tersebut lebih kecil dari 1,000 (Guenther, 1987).

Indeks refraksi merupakan perbandingan antara sudut sinar datang dengan sudut sinar bias bila seberkas sinar jatuh pada suatu larutan. Jika minyak mengandung air, maka nilai indeks refraksinya rendah (Guenther, 1987). Karena banyak minyak atsiri larut dalam alkohol dan jarang yang larut air, maka kelarutannya dapat dengan mudah diketahui dengan menggunakan alkohol pada berbagai tingkat konsentrasi. Biasanya minyak yang kaya komponen oxygenated lebih mudah larut dalam alkohol daripada yang kaya akan terpen.

Kelarutan minyak atsiri dapat berubah karena pengaruh umur. Hal ini disebabkan karena proses polimerisasi menurunkan daya kelarutan, sehingga untuk melarutkannya diperlukan konsentrasi alkohol yang lebih tinggi. Kondisi penyimpanan yang kurang baik juga dapat mempercepat polimerisasi. Faktor-faktor seperti cahaya, udara dan adanya air biasanya menimbulkan pengaruh yang tidak baik (Guenther, 1987). Pengukuran sifatsifat minyak atsiri dimaksudkan untuk menentukan terlebih dahulu sifat dan karakter minyak atsiri yang digunakan dalam penelitian ini. 


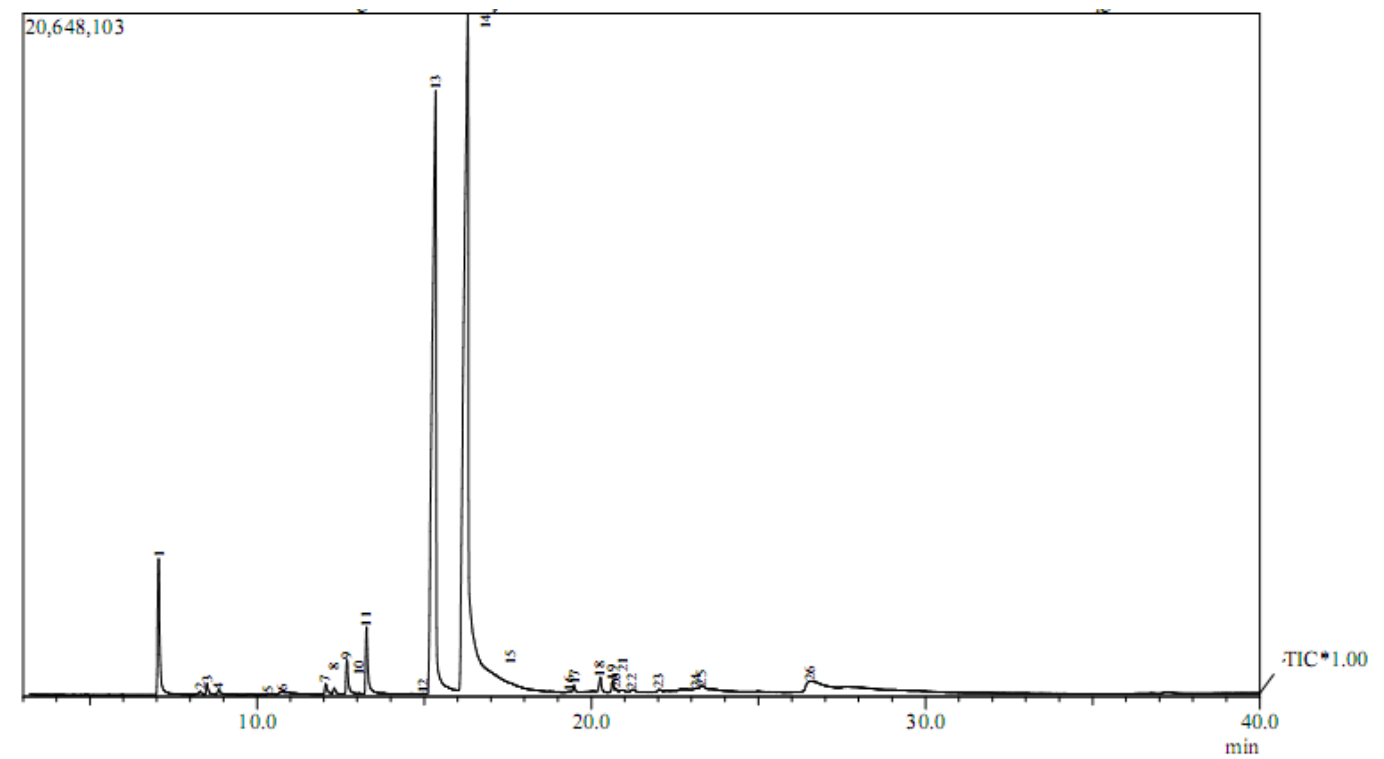

Gambar 1. Kromatogram hasil pengujian minyak atsiri serai dengan menggunakan GC-MS

\section{Komponen Kimia Minyak Serai}

Kromatogram GC-MS dari minyak atsiri serai yang dihasilkan disajikan pada Gambar 1 dan komposisi komponen kimia minyak atsiri serai disajikan Tabel 2.

Tabel 2. Komponen kimia minyak serai

\begin{tabular}{|c|c|c|}
\hline & Komponen kimia & $\begin{array}{c}\text { Persentasi } \\
(\%)\end{array}$ \\
\hline 1 & $\beta$ myrcene & 3,98 \\
\hline 2 & 1,8 cineole & 0,11 \\
\hline 3 & Cis ocimene & 0,31 \\
\hline 4 & 1,3,6-Octatriene 3,7-dimethyl & 0,16 \\
\hline 5 & Myrtenol & 0,03 \\
\hline 6 & L linalool & 0,15 \\
\hline 7 & 1,4- hexadiene & 0,36 \\
\hline 8 & Citronella & 0,23 \\
\hline 9 & Phellandral & 1,08 \\
\hline 10 & Rose furan epoksida & 0,05 \\
\hline 11 & Carane 4,5 epoxy & 2,06 \\
\hline 12 & Oxirane caroxaldehid & 0,02 \\
\hline 13 & z-citral & 34,05 \\
\hline 14 & Citral & 53,77 \\
\hline 15 & Dimetil pinate & 0,03 \\
\hline 16 & Geraniol asetat & 0,05 \\
\hline 17 & Cyclohexane & 0,20 \\
\hline 18 & Trans caryophyllene & 0,51 \\
\hline 19 & $\alpha$-bergomotene & 0,34 \\
\hline 20 & $\alpha$-guaiene & 0,11 \\
\hline 21 & Allo aromadendrene & 0,15 \\
\hline 22 & $\alpha$-humulene & 0,18 \\
\hline 23 & $\alpha$-gorjunene & 0,08 \\
\hline 24 & Germacrene & 0,08 \\
\hline 25 & Delta cadinene & 0,23 \\
\hline 26 & Juniper champor & 1,66 \\
\hline
\end{tabular}

Berdasarkan Gambar 1 dan Tabel 2, dapat dilihat terdapat 26 komponen kimia yang menyusun minyak serai. Komponen utama dalam minyak serai adalah citral $(53,77 \%)$ dan z-citral $(34,05 \%)$. Menurut Violon et al. (1994), citral merupakan salah satu komponen yang memiliki aktivitas antifungal tertinggi diantara kelompok terpenoid. Citral diduga memiliki aktivitas cytotoxic (Bakkali et al., 2008). Pada sel eukarotik, minyak atsiri dapat menyebabkan terjadinya depolarisasi membran mitokondria dengan menurunkan potensial membran sehingga mempengaruhi siklus ion $\mathrm{Ca}^{++}$ serta siklus ionik lainnya dan menurunkan gradient $\mathrm{pH}$ yang mempengaruhi pompa proton dan pembentukan ATP.

Neral atau z-citral yang merupakan isomer citral dan komponen terbesar kedua setelah citral pada minyak serai, dilaporkan memiliki aktivitas anti-jamur. Wuryatomo et al. (2003), menyebutkan bahwa neral konsentrasi $15 \mu \mathrm{L} / \mathrm{L}$ dapat menghambat pertumbuhan $P$. digitatum dan $P$. italicum serta memiliki aktivitas fungisidal terhadap G. candidum pada konsentrasi yang sama.

Selain citral, keberadaan linalool dalam minyak serai juga diduga memiliki pengaruh terhadap aktivitas anti-jamur. Linalool yang merupakan komponen utama minyak basil, dapat menghambat pertumbuhan B. cereus, E. coli dan $L$. monocytogenes pada konsentrasi 20.000 ppm (Gutierrez et al., 2008). Sedangkan penelitian oleh Cantore et al. (2004), menyatakan bahwa minyak $C$. sativum dengan komponen utama linalool memiliki aktivitas bakterisidal yang cukup tinggi terhadap bakteri gram positif dan gram negatif yang diujikan. 
Minyak biji Coriandrum sativum L. yang memiliki komponen utama linalool dilaporkan dapat menghambat, E. coli, L. monocytogenes, S. aureus dan $S$. cerevisiae pada konsentrasi $0,13-0,47 \%$ terhadap $P$. fragi dan $S$. typhimurium tidak menunjukkan aktifitas antimikrobia (Delaquis et al., 2002). Dalam keadaan murni, linalool 12,5 $\mu \mathrm{g} / \mathrm{mL}$ dapat menghambat pertumbuhan $T$. mentagrophytes, meskipun tidak sekuat citral, dengan diameter penghambatan $11 \mathrm{~mm}$ (Shigeharu et al., 2006). Delaquis et al. (2002) menyebutkan bahwa fraksi dari minyak cilantro yang mengandung linalool mampu menghambat pertumbuhan Pseudomonas fragi, Escherecia coli dan Salmonella Typhimurium

Pada minyak serai terdapat komponen 1,8 cineole. Penelitian oleh Vilela et al. (2009), menunjukkan bahwa 1,8-cineole dengan konsentrasi $1,3492 \mu \mathrm{L}$ hanya dapat menghambat $5 \%$ pertumbuhan $A$. flavus dan A. parasiticus. Komponen 1,8-cineole memiliki konsentrasi minimal penghambatan $2,5 \mathrm{mg} / \mathrm{mL}$ dan 1,25 mg/mL terhadap A. flavus dan A. niger (Shin, 2003). Sedangkan terhadap $T$. mentagrophytes, $50 \mu \mathrm{g} / \mathrm{mL}$ 1,8 cineole hanya memiliki zona penghambatan 13 mm (Shigeharu et al., 2006).

Berdasarkan penelitan Tzortzakis (2007), minyak serai memiliki 9 komponen kimia, dengan komponen utama berupa isomer citral, yang terdiri dari geranial sebanyak 40,79\% dan neral sebanyak $31,85 \%$, sementara dalam penelitian ini minyak serai yang didapatkan mengandung citral $(53,77 \%)$ sebagai komponen tertinggi, diikuti $\mathrm{z}$ citral $(34,05 \%)$. Perbedaan komponen kimia penyusun minyak serai dan komposisinya, selain karena perbedaan varietas dapat disebabkan oleh perbedaan kondisi geografis dan iklim tempat tanaman tumbuh atau perbedaan spesifikasi alat dan kondisi pengujian.

\section{Aktivitas Antijamur Minyak Serai}

Hasil pengujian aktivitas antijamur minyak serai pada variasi konsentrasi yang diujikan disajikan foto pertumbuhan jamur pada Gambar 2a dan 2b dan ukuran diameter koloni Gambar 3a dan 3b. Sedangkan persentase penghambatan aspergillus oleh minyak atsiri serai setelah 7 hari disajikan pada Tabel 3.

Gambar 3a dan 3b menunjukkan pola pertumbuhan $A$. flavus dan $A$. parasiticus pada media pertumbuhan dengan penambahan variasi konsentrasi minyak atsiri daun serai selama 7 hari pengamatan. Penundaan pembentukan miselia terjadi mulai konsentrasi minyak atsiri 0,01\% (100 ppm). Semakin tinggi konsentrasi minyak atsiri yang ditambahkan maka germinasi spora akan semakin terhambat. Pada konsentrasi 0,02 \% (200 ppm) A.flavus masih mengalami penundaan pertumbuhan spora sampai 2 hari berikutnya. Pada konsentrasi 0,8\% (800 ppm) terlihat bahwa kedua jenis jamur tidak mampu tumbuh selama 7 hari pengamatan.

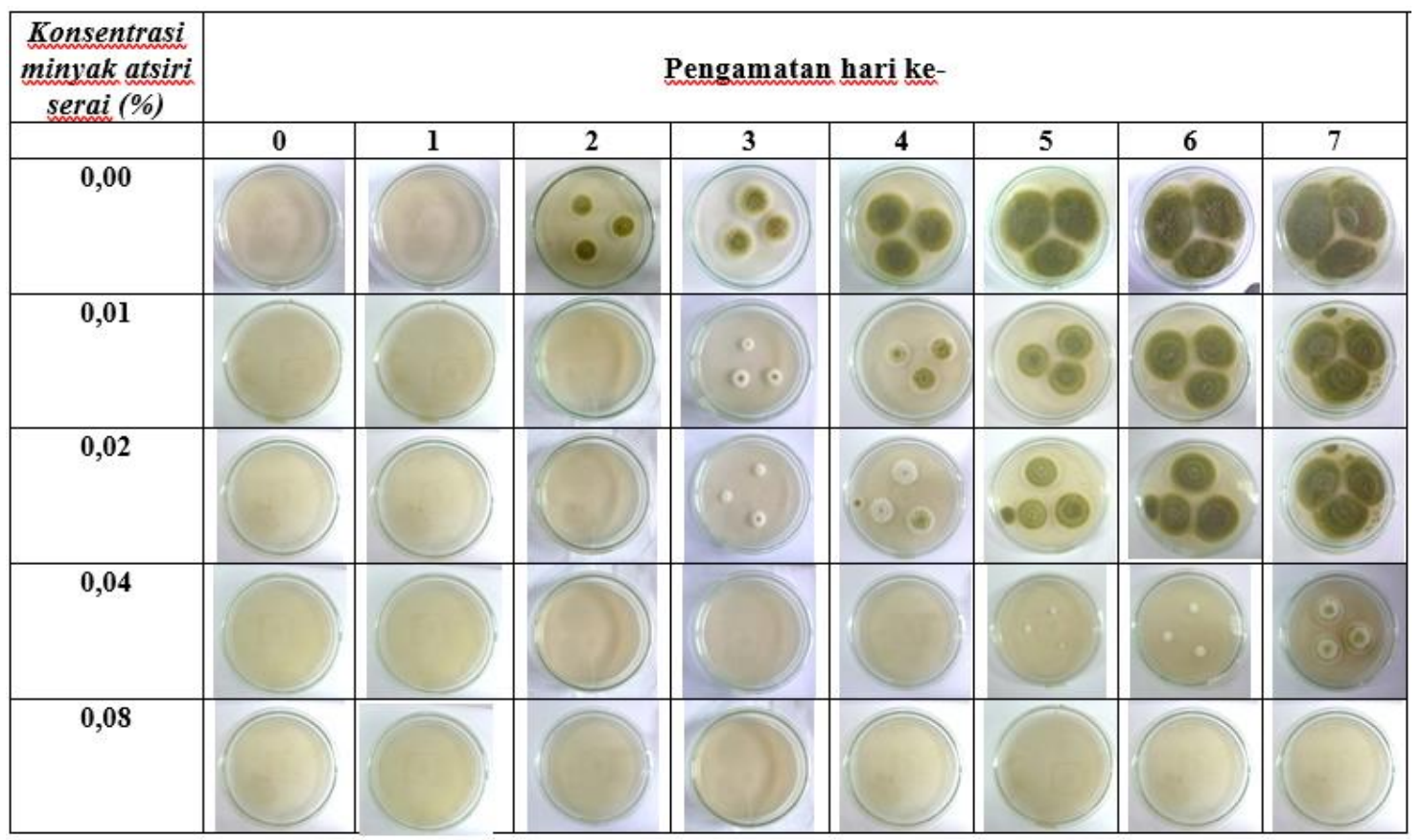

Gambar 2a. Uji aktivitas penghambatan pertumbuhan A. flavus oleh minyak serai 


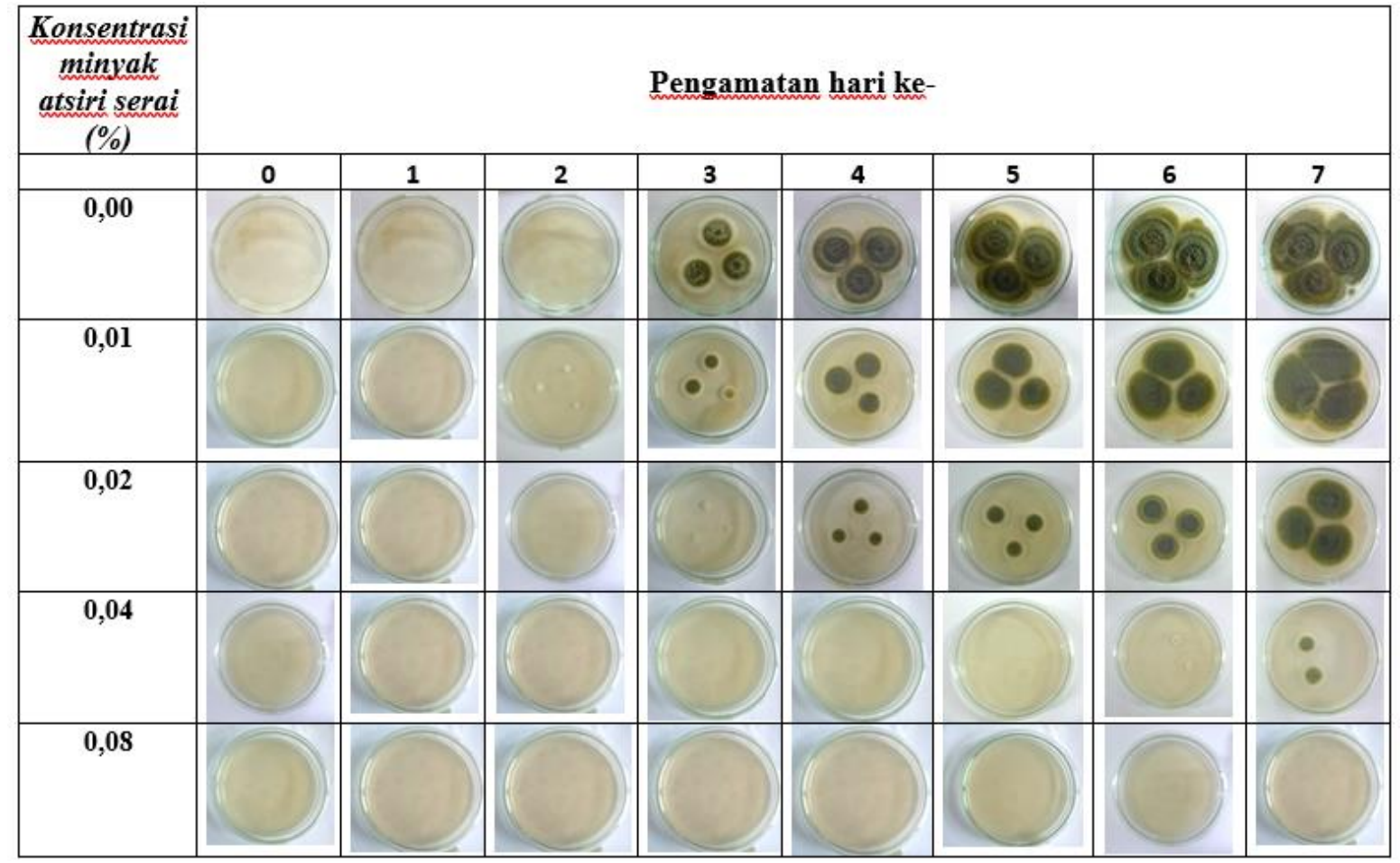

Gambar 2b. Uji aktivitas penghambatan pertumbuhan A. parasiticus oleh minyak serai

Tabel 3. Aktivitas penghambatan pertumbuhan A. flavus dan A. parasiticus setelah 7 hari pada berbagai konsentrasi minyak serai

\begin{tabular}{ccccc}
\hline \multirow{2}{*}{$\begin{array}{c}\text { Konsentrasi } \\
\text { minyak }(\%)\end{array}$} & $\begin{array}{c}\text { A. flavus } \\
\text { Diameter }\end{array}$ & $\begin{array}{c}\text { Persentase } \\
\text { kenghambatan }(\%)\end{array}$ & $\begin{array}{c}\text { Diameter } \\
\text { koloni }(\mathrm{cm})\end{array}$ & $\begin{array}{c}\text { Persentase } \\
\text { penghambatan }(\%)\end{array}$ \\
\hline 0 & 7,50 & $\left.0^{\mathrm{a}}{ }^{*}\right)$ & 7,45 & $\left.0^{\mathrm{a}}{ }^{*}\right)$ \\
0,01 & 6,27 & $16,44^{\mathrm{b}}$ & 6,63 & $10,96^{\mathrm{b}}$ \\
0,02 & 3,41 & $54,56^{\mathrm{c}}$ & 5,02 & $32,66^{\mathrm{c}}$ \\
0,04 & 2,48 & $66,89^{\mathrm{d}}$ & 2,08 & $72,15^{\mathrm{d}}$ \\
0,08 & 0 & $100,00^{\mathrm{e}}$ & 0 & $100,00^{\mathrm{e}}$ \\
\hline
\end{tabular}

Keterangan: *) Tanda huruf yang sama dalam satu kolom menunjukkan hasil yang tidak berbeda nyata pada $\alpha=0,05$

Pada konsentrasi terendah yang diujikan, yaitu $0,01 \%(100 \mathrm{ppm})$, pertumbuhan jamur $A$. flavus dan A. parasiticus telah terhambat sebesar $16,44 \%$ dan $10,96 \%$. Semakin tinggi konsentrasi minyak serai yang digunakan, persentase penghambatan pertumbuhan jamur semakin besar. Pada konsentrasi minyak serai sebesar 0,08\% (800 ppm), A. flavus dan A. parasiticus dapat dihambat $100 \%$ pertumbuhannya selama 7 hari pengamatan. Hasil ini sesuai dengan yang didapatkan oleh Tzortzakis (2007), yang menyebutkan bahwa minyak serai dengan komponen utama isomer citral berupa geranial dan neral mampu menghambat $100 \%$ pertumbuhan $C$. coccodes, C.herbarum, $R$. stolonifera, dan $A$. niger selama 10 hari pada konsentrasi 500 ppm. Kemampuan penghambatan minyak serai, disebabkan oleh komponen kimia penyusun minyak tersebut. Citral yang merupakan komponen utama minyak serai memiliki aktivitas antijamur yang tinggi terhadap T. mentagrophytes, yaitu dapat menghambat $100 \%$ pertumbuhan pada inkubasi suhu $28^{\circ} \mathrm{C}$ selama 10 hari dengan konsentrasi $0,1 \mathrm{mg} / \mathrm{mL}(100 \mathrm{ppm})$ (Park et al., 2009) dan pada konsentrasi $3,13 \mu \mathrm{g} / \mathrm{mL}(3,13 \mathrm{ppm})$ dapat menghambat pertumbuhan jamur tersebut sampai diameter $60 \mathrm{~mm}$ (Shigeharu et al., 2006). Pada konsentrasi $6 \mu \mathrm{L} / \mathrm{L}(6 \mathrm{ppm})$ citral dapat menghambat pertumbuhan $P$. italicum tetapi tidak bersifat fungisidal, sedangkan citral $15 \mu \mathrm{L} / \mathrm{L}$ (15 ppm) bersifat fungisidal terhadap $P$. digitatum and G. candidum (Wuryatmo et al., 2003). Penelitian oleh López-Malo et al. (2005), menunjukkan bahwa 
citral dapat menghambat pertumbuhan A. flavus selama 60 hari dengan konsentrasi 1400-1800 ppm pada kondisi suhu $25^{\circ} \mathrm{C}, \mathrm{pH} 3,5$ dan 4,5 , serta $a_{w}$ 0,95 dan 0,99 .

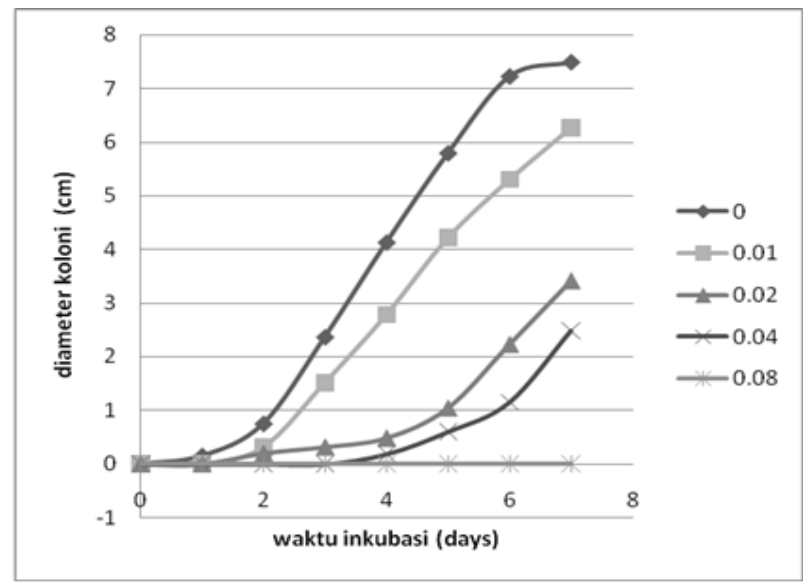

Gambar 3a. Pengaruh konsentrasi minyak serai terhadap pertumbuhan A. flavus

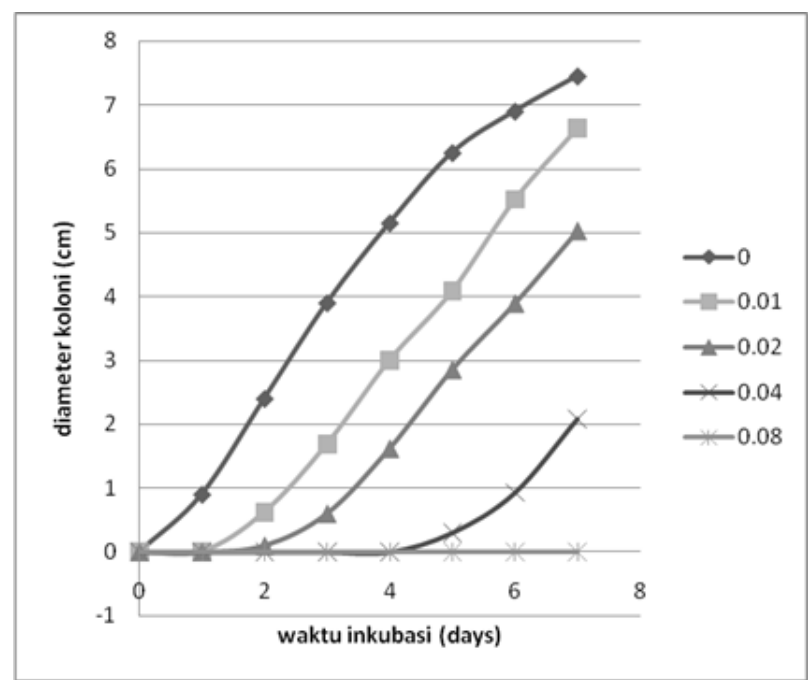

Gambar 3b. Pengaruh konsentrasi minyak serai terhadap pertumbuhan A. parasiticus

Aktivitas antimikrobia pada minyak atsiri dapat disebabkan oleh komponen tunggal atau sinergisitas maupun antagonisitas komponenkomponennya. Pada penelitian ini, minyak serai yang digunakan menunjukkan kadar citral yang tinggi $(53,77 \%)$ dan z-citral $(34,05 \%)$. Kedua komponen tersebut mempunyai sifat anti jamur yang tinggi dibandingkan terpen yang lain (Violon, 1994; Wuryatmo, 2003). Sehingga kedua senyawa inilah yang sangat mungkin menyebabkan sifat anti jamur dari minyak serai, sehingga mampu menghambat pertumbuhan jamur $A$. flavus dan $A$. parasiticus.
Selain itu linalool dan 1,8 cineole yang juga terdapat dalam minyak atsiri serai juga punya sifat anti jamur (Delaquis et al., 2002; Guiterrez et al., 2008; Vilela et al., 2010). Walaupun linalool dan 1,8 cineole merupakan komponen minor pada minyak serai, namun menurut Burt (2004) pengaruh sinergis dari komponen minor dapat menjadi bagian penting pada aktifitas antimikrobia. Kombinasi citral dan linalool dalam perbandingan tertentu dilaporkan dapat meningkatkan aktivitas antimikrobia (Belletti et al., 2010). Mengingat kandungan linalool dalam penelitian ini hanya $0,15 \%$, maka berdasarkan penelitian-penelitian lain diduga efek anti jamur yang dihasilkan serai yang digunakan dalam penelitian ini adalah karena efek kombinasi antara citral dan linalool.

Mekanisme terjadinya penghambatan pertumbuhan jamur oleh minyak atsiri disebabkan oleh komponen minyak atsiri dapat melewati membran sel, berikatan dengan enzim dan protein membran serta memghasilkan fluks proton ke arah eksterior sel yang mempengaruhi perubahan dalam sel dan akhirnya menyebabkan kematian sel (Omidbeygi et al., 2007). Menurut Marino et al. (2001), komponen minyak atsiri mampu terpenetrasi ke dalam sel dan menggangu metabolisme sel. Selain itu, Chang et al. (2001) menyatakan bahwa komponen minyak atsiri mampu menggangu membran sel dan bereaksi dengan sisi aktif enzim atau berperan sebagai carier $\mathrm{H}^{+}$. Tatsadjieu et al. (2009) mengemukakan bahwa pada sistem transport sel, untuk memompa proton dilakukan oleh $\mathrm{H}^{+}$-ATPase yang sangat penting untuk regulasi $\mathrm{pH}$ internal sel jamur. Enzim ATPase menjaga homeostasis sel dan stabilitas osmotik sel dengan mengatur konsentrasi ion di dalam sel. Minyak atsiri mampu berikatan dengan enzim ATPase sehingga menyebabkan sistem transport terganggu dan tidak dapat memompa proton keluar dari sel. Pada kondisi normal, substrat glukosa dengan cepat dibawa oleh sistem transport dibantu dengan pengeluaran proton dari sel oleh ATPase pada membran plasma sehingga terjadi penurunan pH supensi sel tersebut. Tatsadjieu et al. (2009), menyatakan bahwa minyak atsiri dari daun Lippia rugosa mampu menghambat aktivitas enzim ATPase sehingga tidak terjadi penurunan $\mathrm{pH}$ pada suspensi sel karena sistem transport terganggu.

\section{KESIMPULAN}

Komponen kimia yang dapat teridentifikasi dari minyak serai (Cymbopogon citratus) adalah 26 jenis senyawa, dengan komponen utama citral 
$(53,77 \%)$ dan z-citral $(34,05 \%)$. Sifat anti-jamur dari minyak serai dapur ini, diduga karena peran citral yang ada di dalam minyak atsiri tersebut. Penambahan minyak serai ( $C$. citratus) pada konsentrasi rendah (100 ppm) sudah menunjukkan kemampuan penghambatan terhadap pertumbuhan jamur dan pada konsentrasi 0,08\% (800 ppm) memiliki kemampuan menghambat pertumbuhan jamur sebesar $100 \%$. Untuk penelitan lebih lanjut, perlu diuji komponen mana yang berperan sebagai anti jamur pada A. flavus dan A. parasiticus, dan komponen mana pada minyak serai dapur yang lebih berperan sebagai pemberi aroma. Isolasi komponen tersebut perlu dilakukan untuk mendapatkan anti jamur yang baik, dengan aroma yang tidak terlalu kuat.

\section{DAFTAR PUSTAKA}

Bakkali, F., S. Averbeck, D. Averbeck, and M. Odaomar. 2008. Biological effects of essential oils - A review. Food and Chemical Toxicology 46: 446-475. DOI: 10.1016/j.fct.2007.09.106

Bluma, R.V. and M.G. Etcheverry. 2007. Application of essential oils in maize grain: Impact on Aspergillus section Flavi growth parameters and aflatoxin accumulation. Food Microbiology 25: 324-334. DOI: 10.1016/j.fm.2007.10.004

Belletti, N., S.S. Kamdem, G. Tabanelli, R. Lanciotti, and F. Gardini. 2010. Modeling of combined effects of citral, linalool and $\beta$ pinene used against Saccharomyces cerevisiae in citrus-based beverages subjected to a mild heat treatment. International Journal of Food Microbiology 136: 283-289. DOI: 10.1016/j.ijfoodmicro. 2009.10.030

Cantore, P.L., N.S. Iacobellis, A. de Marco, F. Capasso, and F. Senatore. 2004. Antibacterial activity of Coriandrum sativum L. and Foeniculum vulgare Miller var. vulgare (Miller) essential oils. Journal of Agriculture and Food Chemistry 52: 7862-7866. DOI: $10.1021 / \mathrm{jf0} 493122$

Chang, H.T., Y.H. Cheng, C.L. Wu, S.T. Chang, T.T. Chang, and Y.C. Su. 2008. Antifungal activity of essential oil and its constituents from Calocedrus macrolepis var. formosana Florin leaf against plant pathogenic fungi. Bioresource Technology 99: 6266-6270. DOI: $10.1016 /$ j.biortech.2007.12.005
Davari, E., M. Mohsenzadeh, G. Mohammadi, and R. Rezaeian-Doloei. 2015. Characterization of aflatoxigenic Aspergillus flavus and $A$. parasiticus strain isolates from animal feedstuffs in northeastern Iran. Iranian Journal of Veterinary Research 16: 150-155.

Delaquis, P.J., K. Stanich, B. Girard, and G. Mazza. 2002. Antimicrobial activity of individual and mixed fractions of dill, cilantro, coriander and eucalyptus essential oils. International Journal of Food Microbiology 74: 101-109. DOI: 10.1016/s01681605(01)00734-6

De Billerbeck, V.G., C.G. Roques, J.M. Bessière, J.L. Fonvieille, and R. Dargent. 2001. Effect of Cymbopogon nardus (L) W. Watson essential oil on the growth and morphogenesis of Aspergillus niger. Canadian Journal of Microbiology 47: 9-17. DOI: $10.1139 /$ w00-117

Guenther, 1987. Minyak Atsiri Vol I-IV. Terjemahan Ketaren. Jakarta: UI Press.

Gutierrez, J., C. Barry-Ryan, and P. Bourke. 2008. The antimicrobial efficacy of plant essential oil combinations and interactions with food ingredients. International Journal of Food Microbiology 124: 91-97. DOI: 10.1016/j.ijfoodmicro.2008.02.028

López-Malo, A., S.M. Alzamora, and E. Palou. 2005. Aspergillus flavus growth in the presence of chemical preservatives and naturally occurring antimicrobial compounds. International Journal of Food Microbiology 99: 119-128. DOI: 10.1016/j.ijfoodmicro.2004.08.010

Marino, M., C. Bersani, and G. Comi. 2001. Impedance measurements to study the antimicrobial activity of essential oils from Lamiaceae and Compositae. International Journal of Food Microbiology 67: 187-195. DOI: 10.1016/s0168-1605(01)00447-0

Omidbeygi, M., M. Barzegar, Z. Hamidi, and H. Naghdibadi. 2007. Antifungal activity of thyme, summer savory, and clove essential oils against Aspergillus flavus in liquid medium and tomato paste. Food Control 18: 1518-1523. DOI: 10.1016/j.foodcont.2006. 12.003

Tatsadjieu, N.L., P.M.J. Dongmo, M.B. Ngassoum, F-X. Etoa, and C.M.F. Mbofung. 2009. Investigations on the essential oil of Lippia rugosa from Cameroon for its potentials use as antifungal agents against Aspergillus 
flavus Link ex fries. Food Control 20: 161166. DOI: 10.1016/j.foodcont.2008.03.008

Park, M.J., K.S. Gwak, I. Yang, K.W. Kim, E.B. Jeung, J.W. Chang, and I.G. Choi. 2009. Effect of citral, eugenol, nerolidol and $\alpha$ terpineol on the ultrastructural changes of Trichophyton mentagrophytes. Fitoterapia 80: 290-296. DOI: 10.1016/j.fitote.2009. 03.007

Perrucci, S., F. Mancianti, P.L. Cioni, G. Flamini, I. Morelli, and G. Macchioni. 1994. In vitro antifungal activity of essential oil against some isolate of Microsporum canis and Microsporum gypseum. Planta Medica 60: 184-187. DOI: 10.1055/s-2006-959448

Sardjono, E.S. Rahayu, A.D. Hocking, and J.I. Pitt. 1992. Mycroflora of cereals and nuts from Indonesia. Proc. the 4th ASEAN Food Conference, Jakarta.

Shigeharu, I., U. Katsuhisa, and A. Shigeru. 2006. Vapor activity of 72 essential oils against a Trichophyton mentagrophytes. Journal of Infection and Chemotherapy 12: 210-216. DOI: $10.1007 / \mathrm{s} 10156-006-0449-8$.

Shin, S. 2003. Anti-aspergillus activities of plant essential oils and their combination effects with ketoconazole or amphotericin B. Archives of Pharmacal Research 6: 389-393. DOI: 10.1007/BF02976696

Tripathi, A., N. Sharma, and V. Sharma. 2009. In vitro efficacy of Hyptis suaveolens L. (Poit.) essential oil on growth and morphogenesis of Fusarium oxysporum f.sp. gladioli (Massey) Snyder \& Hansen. World Journal of Microbiology and Biotechnology 25: 503512.

Tzortzakis, N.G. and C.D. Economakis. 2007. Antifungal activity of lemongrass (Cympopogon citratus L.) essential oil against key postharvest pathogens. Innovative Food Science \& Emerging Technologies 8: 253-258. DOI: 10.1016/j.ifset.2007.01.002

Vilela, G.R., G.S. de Almeida, M.A.B.R. D’Arce, M.H.D. Moraes, J.O. Brito, M.F.G.F. da Silva, S.C. Silva, S.M.S. Piedade, M.A. Calori-Domingues, and E.M. da Gloria. 2009. Activity of essential oil and its major compound, 1,8-cineole, from Eucalyptus globulus Labill., against the storage fungi Aspergillus flavus Link and Aspergillus parasiticus Speare. Journal of Stored Products Research 45: 108-111. DOI: 10.1016/j.jspr.2008.10.006

Violon, C. and J.P. Chaumont. 1994. Antifungal properties of essential oils and their main components upon Cryptococcus neoformans. Mycopathologia 128: 151-153. DOI: 10.1007/BF01138476

Wuryatmo, E., A. Klieber, and E.S. Scott. 2003. Inhibition of citrus postharvest pathogens by vapor of citral and related compounds in culture. Journal of Agriculture Food Chemistry 51: 2637-2640. DOI: 10.1021/jf0261831

Tatsadjieu, N.L., P.M.J. Dongmo, M.B. Ngassoum, F-X. Etoa, and C.M.F. Mbofung. 2009. Investigations on the essential oil of Lippia rugosa from Cameroon for its potentials use as antifungal agents against Aspergillus flavus Link ex fries. Food Control 20: 161166. DOI: 10.1016/j.foodcont.2008.03.008

Yanti, R., P. Wulandari, Y. Pranoto, dan M.N. Cahyanto. 2018 Karakterisasi, identifikasi dan uji aktivitas anti jamur minyak atsiri daun jeruk purut (Citrus hystrix) terhadap Aspergillus. Jurnal Teknologi Pertanian Unsrat 8: 8-1. 